\title{
USING THREE-TIER TeST TO IDENTIFY THE QUANTITY OF STUDENT THAT HAVING Misconception On NeWTON'S LAWS OF MOTION CONCEPT
}

\author{
Emi Sulistri ${ }^{1)}$, Lisdawati $^{2)}$ \\ 1) High School Teacher Training and Education Singkawang, Singkawang, Indonesia \\ E-mail: sulistriemi@gmail.com \\ 2) High School Teacher Training and Education Singkawang, Singkawang, Indonesia \\ E-mail: lisdajfc@gmail.com
}

\begin{abstract}
This study aims to identify students quantity who are having the misconception on Newton's laws of motion concept using a Three-tiered Test. The sampling technique used in this study is purposive sampling technique and has been conducted on 56 students at Senior High School. A three-tier "Newton's Law Of Motion Test" with 10 items is using as instrument to collected date in this study. The results showed that the quantity of students who experienced misconception with the highest category is on the concept of determining the relationship between the mass of objects and the time required for free fall that is equal to $89.3 \%$. While the lowest category is in the concept of explaining the relationship between acceleration, mass and force with the time required for the object to fall freely that is equal to $26.8 \%$.
\end{abstract}

Keywords: misconception, three-tier test, Newton's laws of motion.

\section{INTRODUCTION}

Often found students who have a different concept with experts or scientifically or better known as misconception. misconceptions is used for students' ideas that differ from the definitions accepted by experts [1], contradiction or incompatibility of the concept that is understood by the concept of a person who used the corresponding science experts [2].

Misconceptions are stable, unscientific conceptions that obstacle the real learning of individuals [3]. Hammer [4] listed the properties of misconceptions as: (a) These conceptions are strongly held, stable cognitive structures (b) They differ from expert conceptions (c) They affect how students understand natural phenomena and scientific explanations (d) They must be overcome, avoided or eliminated. For this reason, identification and elimination of misconceptions about several science concepts is a popular research area in educational research [5].

There have been numerous studies indicating that students' misconceptions have considerable influence on students' learning of fundamental science concepts and the subsequent more advanced concepts [6-9]. Particularly in the concept of physics, Wandersee mentions in his research that of the 700 studies of alternative concepts in the field of physics, there are 300 who examine the misconceptions in the field of mechanics, 159 on electricity, 70 about heat, optics and material properties,
35 about earth and outer space and 10 study of modern physics [10]. That is, the case of misconception in the field of mechanics is ranked at the top and until now still a problem that never ends in the world of education. Therefore, the identification of student misconceptions is very important for effective teaching planning and remediation of students' difficulties in understanding the concept of science, especially physics, so that the quantity of students experiencing misconception can be overcome and not increase.

Although there are a variety of methods to diagnose students' misconceptions in science, such as with interviews, multiplechoice test, Two-Tier Test, Force Concept Inventory (FCI), Certainly Response Index (CRI) and Three-Tier Test. In particular the Three-tiered Test is the development of twotiered multiple-choice test combined with Certainly Response Index (CRI) resulting in three levels matter consisting of first level (one tier) to measure student comprehension, second level (two tier) in the form of a selection of reasons and third level (three tier) in the form of an affirmation of belief over the previous answer [11]. With the three tier test, will certainly make it easier for researchers to obtain more information and accurately about the misconception of students so that students understand concepts, misconceptions and don't understand the concept can be distinguished. For this reason one of the aims of this study is to identify quantity of student who are having the 


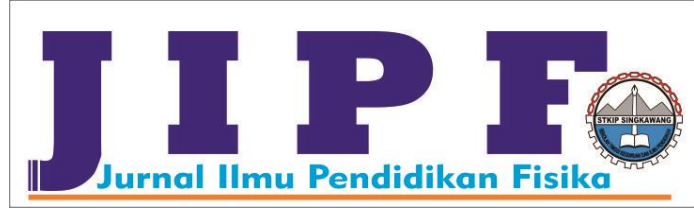

misconception on Newton's laws of motion concept using a Three-tiered Test.

\section{METHODS}

This study is quantitative research, with descriptive approachand has been conducted on 56 students at Senior High School in Selakau. The sampling technique used in this study is purposive sampling technique in which the way of taking samples based on specific objectives [12]. A three-tier "Newton's Laws Of Motion Test" with 10 items which measures misconceptions was developed by the researchers and 1 item is grains of matter represent 1 the concept of motion. Distribution of the concept of Newton's laws of motion can be seen in Table 1.

TABLE. 1

DISTRIBUTION OF THE CONCEPT OF NEWTON'S LAWS OF MOTION

\begin{tabular}{|c|c|}
\hline Items & Concept \\
\hline 1 & $\begin{array}{l}\text { The force acting on a stationary object corresponding } \\
\text { Newton's first law }\end{array}$ \\
\hline 2 & $\begin{array}{l}\text { The magnitude of the normal force and gravity of the } \\
\text { object on the incline is in accordance with first law }\end{array}$ \\
\hline 3 & $\begin{array}{l}\text { The concept of equilibrium under the Newton's first } \\
\text { laws }\end{array}$ \\
\hline 4 & $\begin{array}{l}\text { Pair style action-reaction on the body according to the } \\
\text { Newton's third law }\end{array}$ \\
\hline 6 & $\begin{array}{l}\text { The relationship between the size of the object with } \\
\text { wakt the required objects to free fall motion }\end{array}$ \\
\hline 7 & $\begin{array}{l}\text { The relationship between the mass of the object and the } \\
\text { time require objects to free fall }\end{array}$ \\
\hline 8 & $\begin{array}{l}\text { The relationship between force, acceleration and mass } \\
\text { of the object }\end{array}$ \\
\hline 9 & $\begin{array}{l}\text { The acceleration due to gravity for two objects with } \\
\text { different masses }\end{array}$ \\
\hline 10 & $\begin{array}{l}\text { The relationship between the acceleration due to gravity } \\
\text { and mass of the object }\end{array}$ \\
\hline
\end{tabular}

\section{RESULTS AND DISCUSSION}

\section{A. Results}

Analysis of test data is done by calculating the proportion of students who answered correctly and the students who answered incorrectly to determine whether or not the student confident in answering questions on a three-tier test. Based on the analysis, the quantity of students who have misconceptions of the 10 items (10 concept of motion), can be seen in Figure 1.

According to Figure 1, it can be seen that the quantity of students who have the highest misconceptions exist on the concept of 7 , with indicators determining the relationship between the mass objects and the time required for the free fall of $89.3 \%$. While the quantity of students who have misconceptions with the lowest category contained in the concept of 8 indicators determine the relationship of style, speed and mass of the object by $26.8 \%$. However, there is no equality of the misconceptions the students to the concept of 5 and 10 concept that is equal to $33 \%$.
Jurnal Ilmu Pendidikan Fisika

Volume 2 Number 1 month March 2017. Page 4-6 p-ISSN: 2477-5959 e-ISSN: 2477-8451

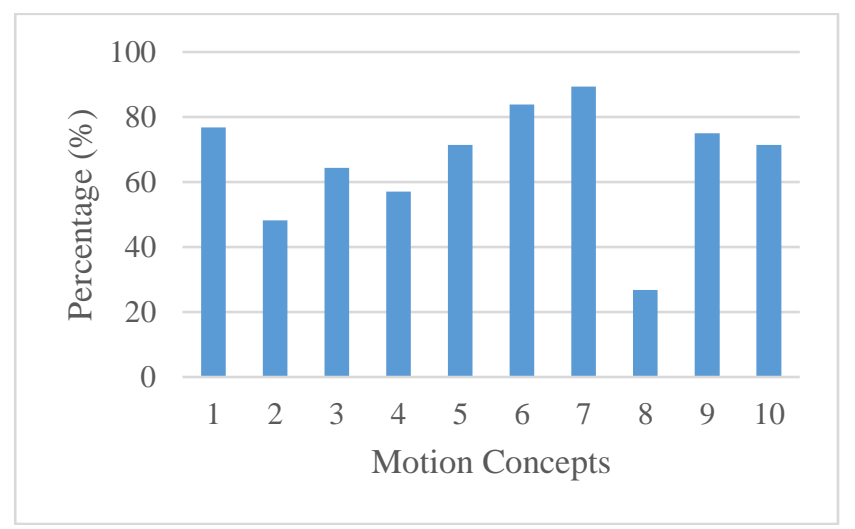

Figure 1. The percentage of the quantity of student who have Misconceptions

For more details, quantity of students who have misconceptions on each concept can be seen in Table 2 .

TABLE. 2

QUANTITY OF STUDENTS THAT HAVING MisCONCEPTIONS

\begin{tabular}{cccc}
\hline & \multicolumn{2}{c}{$\begin{array}{c}\text { Quantity of Students that } \\
\text { Having Misconceptions }\end{array}$} & \\
\cline { 2 - 3 } Items & $\begin{array}{c}\text { Total } \\
\text { Students }\end{array}$ & Percentage (\%) & \\
\hline 1 & 43 & 76,8 & High \\
2 & 27 & 48,2 & Medium \\
3 & 36 & 64,3 & Medium \\
4 & 32 & 57,1 & High \\
5 & 40 & 71,4 & High \\
6 & 47 & 83,9 & High \\
7 & 50 & 89,3 & High \\
8 & 15 & 26,8 & Low \\
9 & 42 & 75 & High \\
10 & 40 & 71,4 & High \\
\hline
\end{tabular}

Table 2 provides the information that the quantity of students who have misconceptions largely dominated in the high category, two concepts in the medium category and one concept in the low category.

\section{B. Discussion}

Based on the analysis of students' answers, found that of the 56 students who took the test, 50 or $89.3 \%$ of students experiencing misconceptions in determining the relationship of mass and the time required for falling objects free. this shows that the understanding of students on This concept is still very low. This misconception can be said to dominate for most students assume that the greater the mass of the object then quickly fell to earth semakit. These findings are similar to research Kurniawan and Aref [13] stating that the student has prakonsep wrong, that if two objects dropped at the same height with the mass of the ball is different, the object has a mass heaviest hit the ground first and have time faster than ang object has a mass lighter. Yet according to the concepts of physics is true, to a certain location on the earth and in the absence of air resistance, all objects that fall will experience the same acceleration [14]. This error is caused by a student's experience in everyday life where when a piece of paper and a pebble is 


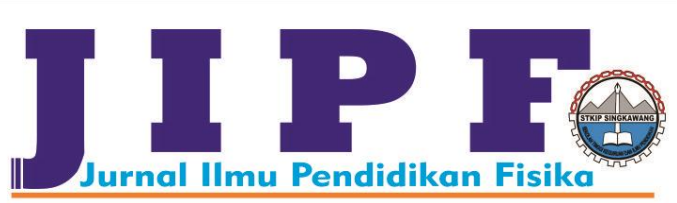

dropped simultaneously on the same elevation, then the gravel will fall first to the ground. Students assume that the pebbles fall faster because it is heavier than paper, whereas the difference between the two objects fall due to the influence of external forces such as air friction. If the friction force is removed, then the two objects will fall simultaneously.

The quantity of students misconceptions lowest for the concept determine the relationship between force, acceleration and mass of the object which only amounted to $26.8 \%$. That is, most of the students' understanding of these concepts are already quite high. Students already understand well the relationship between force, acceleration and mass of the object in accordance with the second law of Newton. That is to say students better understand the questions that are a matter, the decomposition of the force on the object, but the student is weak in understanding about the nature concept [13].

\section{CONCLUSION}

Based on research conducted, in general it can be concluded that the quantity of students misconceptions on the concept of Newton's laws of motion in one of SMA Selakau is as follows.

1. The percentage of students who have the highest misconceptions contained in the concept of determining the relationship of mass and the time required for the free fall of $89.3 \%$.

2. The percentage of students who have misconceptions lowest for the concept of determining the relationship between force, mass and acceleration of the object by $26.8 \%$.

\section{ACKNOWLEDGMENTS}

The authors are grateful to the head of a high school teacher training and education Singkawang. The author is indebted to teachers in Junior High School of Selakau district on cooperation in the completion of this study. Author is also very grateful to my family for their support.

\section{REFERENCES}

[1] Kirbulut, Z. D. \& Geban, U. 2014. Using Three-Tier Diagnostic Test to Assess Students' Misconceptions of States of Matter. Eurasia Journal of Mathematics, Science \& Technology Education, 10(5), 509-521.

[2] Liliawati \& Ramalis. 2009. Identifikasi miskonsepsi materi IPBA di SMA dengan menggunakan CRI (certainly Response Index) dalam upaya perbaikan urutan pemberian materi IPBA pada KTSP. Prosiding seminar nasional penelitian, pendidikan dan penerapan MIPA, 159-168.

[3] Kaltakci, D. \& Didis, D. (2007). Identification of preservice physics teachers'misconceptions on gravity concept: A study with a 3-tier misconception test. In S. A. Çetin, \& İ. Hikmet (Eds.), Proceedings of the American Institute of Physics, USA, 899, 499-500.

[4] Hammer, D. 1996. More than misconceptions: Multiple perspectives on student knowledge and reasoning, and an appropriate role for education research. American Journal of Physics, 64 (10) : 1316-132.
Jurnal Ilmu Pendidikan Fisika

Volume 2 Number 1 month March 2017. Page 4-6 p-ISSN: 2477-5959 e-ISSN: 2477-8451

[5] Kaltakci, D. \& Eryilmaz, A. 2010. Identifying Pre-service Physics Teachers' Misconceptions with Three-tier Tests. http://www.univ-reims.fr/site/evenement/girep-icpemptl-2010-reims-internationalconference/gallery_files/site/1/90/4401/22908/29321/29 329.pdf. Diakses tanggal 12 Oktober 2017.

[6] Artdej, R., Ratanaroutai, T., \& Coll, R. K. (2010). Thai grade 11 students' alternative conceptions for acid-base chemistry. Research in Science \& Technological Education, 28(2), 167-183.

[7] Ayas, A., Ozmen, H., \& Calik, M. (2010). Students' conceptions of the particulate nature of matter at secondary and tertiary level. International Journal of Science and Mathematics Education, 8(1), 165-184.

[8] Tytler, R. (2000). A comparison of year 1 and year 6 students' conceptions of evaporation and condensation: Dimensions of conceptual progression. International Journal of Science Education, 22(5), 447-467.

[9] Voska, K. W., \& Heikkinen, H. W. (2000). Identification and analysis of student conceptions used to solve chemical equilibrium problems. Journal of Research in Science Teaching, 37(2), 160-176.

[10] Suparno. 2005. Miskonsepsi dan Perubahan Konsep Dalam Fisika. Jakarta: PT. Grasindo.

[11] Pesman. 2005. Development of a three tier test to asses ninth grade students' misconceptions about simple electric circuits. Master thesis, middle east tehnical University, Turkey.

[12] Arikunto. 2013. Prosedur Penelitian Suatu Pendekatan Praktik. Jakarta: Rineka Cipta.

[13] Kurniawan, R \& Arief, A. 2015. Identifikasi Miskonsepsi Hukum Newton Tentang Gerak Bagi Siswa Sekolah Menengah Atas Di Kabupaten Nganjuk. Jurnal Inovasi Pendidikan Fisika (JIPF), 04(02), 1-3.

[14] Gincoli, Douglas. 1998. Fisika Jilid I (terjemahan). Jakarta: Erlangga. 